\title{
Inoculation Effect of Consortium of Rhizobium, PSB and KMB on the Growth and Yield of Soybean
}

\author{
J. R. Ghadge and D. R. Murumkar* \\ Department of Plant Pathology and Agril. Microbiology, College of Agriculture, \\ Pune-411 005, Maharashtra, India \\ *Corresponding author
}

\begin{tabular}{l} 
Ke y w o r d s \\
Consortium, \\
Rhizobium, PSB, \\
KMB, Soybean, \\
Yield \\
\hline Article Info \\
$\begin{array}{l}\text { Accepted: } \\
15 \text { August } 2020 \\
\text { Available Online: } \\
10 \text { September } 2020\end{array}$ \\
\hline
\end{tabular}

A B S T R A C T

A field experiment was conducted to study the effect of seed inoculation of consortium of Rhizobium, PSB and KMB on growth parameters, nutrient uptake and yield of soybean. Among different inoculation treatments, seed inoculation with consortium of Rhizobium, PSB and $\mathrm{KMB}+75 \% \mathrm{RDF}$ was found to be the most effective as it recorded significantly highest germination (97.34\%), shoot length $(23.03 \mathrm{~cm})$, root length $(11.60 \mathrm{~cm})$ and plant vigour index $(3370.47)$ at 15 days after sowing, plant height $(33.47 \mathrm{~cm}$ and $44.83 \mathrm{~cm})$, root length $(13.45 \mathrm{~cm}$ and $19.47 \mathrm{~cm})$, dry weight of shoot $\left(7.65 \mathrm{~g} \mathrm{plant}^{-1}\right.$ and $\left.8.90 \mathrm{~g} \mathrm{plant}^{-1}\right)$ and dry weight of root $\left(905.33 \mathrm{mg}\right.$ plant $^{-1}$ and $978 \mathrm{mg}$ plant $\left.^{-1}\right)$ at flowering and harvest stage of the crop, number of branches (5.67 plant $^{-1}$ ), number of nodules (20.93 plant $\left.^{-1}\right)$, number of pods (55.23 plant $\left.^{-1}\right), 1000$ seed weight (125.36 g), NPK uptake (48.56, 12.10 and $22.67 \mathrm{~kg} \mathrm{ha}^{-1}$, respectively) and seed yield $\left(19.48 \mathrm{q} \mathrm{ha}^{-1}\right)$ of soybean, however it was statistically at par with the treatment of seed inoculation with consortium $+100 \%$ RDF for growth parameters, nutrient uptake and seed yield of soybean. The results indicated $25 \%$ saving of nitrogen, phosphorus and potassium dose of chemical fertilizers to soybean.

\section{Introduction}

The soybean plants in symbiotic association with Bradyrhizobium japonicum, can fix up to $200 \mathrm{~kg} \mathrm{~N} \mathrm{ha}^{-1} \mathrm{yr}^{-1}$ (Smith \& Hume, 1987), reducing the need for expensive and environmentally damaging nitrogen fertilizer. Nodulation of soybean requires specific Bradyrhizobium species (Abaidoo et al., 2007). The nitrogen demand of soybean can be supplied via biological nitrogen fixation through the inoculation with selected Bradyrhizobium japonicum strains. Soybean requires $50 \mathrm{~kg} \mathrm{~N}, 75 \mathrm{~kg} \mathrm{P}_{2} \mathrm{O}_{5}$ and $45 \mathrm{~kg} \mathrm{~K} \mathrm{~K}_{2} \mathrm{O}$ for its growth. It is well known that, phosphate solubilizing bacteria (PSB) and Rhizobium have synergistic effect on legume crops (Cao et al., 2016). Development of consortia containing one strain of Rhizobium, PSB and PGPR has been attempted (Bansal 
2015), whereas potash mobilizing bacteria increased ' $\mathrm{K}$ ' availability in soils and increased mineral uptake by plants (Sheng and Huang 2002). Biofertilizers keep the soil environment rich in all kinds of micro and macro nutrients via nitrogen fixation, phosphate solubilization, potash mobilization and release of plant growth regulating substances (Javaid 2009). Shete et al., (2019) formulated MS III culture medium for growth of nitrogen fixing, phosphate solubilizing and potash mobilizing bacteria in a consortium. Keeping this in view, the present research work was undertaken to study effect of consortium of nitrogen fixing, phosphate solubilizing and potash mobilizing bacteria on growth, nutrient uptake and yield of soybean.

\section{Materials and Methods}

\section{Isolation of Rhizobium from root nodules of soybean}

The healthy, unbroken, firm and pink nodules from soybean roots were selected for isolation of Rhizobium by using yeast extract mannitol agar (YEMA) media as described by Rajendran et al., (2008).

\section{Biochemical and physiological characterization of rhizobial isolates}

Pure culture of the isolate was made and then subjected to Gram reaction. The Gram negative isolates were further subjected to biochemical tests including catalase, oxidase, gelatin hydrolysis, indole tests and growth on different carbon sources for confirmation. The biochemical characterization of the isolates was carried out as per the procedures outlined by Cappuccino and Sherman (1987) in their $10^{\text {th }}$ edition of Microbiology: A Laboratory Manual.

Nitrogen fixing ability of the rhizobial isolate: The 48 hour old culture of freshly isolated Rhizobium strain was inoculated to $5 \mathrm{ml}$ of yeast extract mannitol medium. It was incubated for 48 hours. One $\mathrm{ml}$ of this broth was inoculated to $50 \mathrm{ml}$ yeast extract mannitol medium. Then it was incubated for 15 days. Ten $\mathrm{ml}$ of this culture was used for $\mathrm{N}$ estimation by following the standard procedure of Microkjeldhal technique (Reis $e t$ $a l .$, 1994). The formula for $\mathrm{N}_{2}$ estimation is:

$\mathrm{N}_{2}(\mathrm{mg} / \mathrm{g})=$

$\mathrm{ml}$ of $\mathrm{H}_{2} \mathrm{SO}_{4}$ in the sample $\mathrm{x}$ Normality of $\mathrm{H}_{2} \mathrm{SO}_{4} \times 14.01$

Weight of the sample (carbon used in g)

Isolation of phosphate solublizing bacteria (PSB) from rhizosphere soil of soybean

The isolation of phosphate solublizing bacteria on Pikovskaya's medium was carried out by serial dilution of soil and agar plating method (Aneja, 2003). The formation of clear zone of P-solublization around the colonies grown on Pikovskaya's medium were selected, purified, subcultured and maintained on the slants of Pikovskaya's agar for further use.

\section{Phosphate solublizing ability of the bacterial isolates}

The ability of the bacterial isolates to solubilize insoluble inorganic phosphate was tested by spotting $10 \mu \mathrm{l}$ overnight cultures on Pikovskaya's agar plates and incubating at $28-30^{\circ} \mathrm{C}$ for $2-3$ days. The isolates which showed clear zone of solublization of tricalcium phosphate (TCP) around the colony were noted as phosphate solubilizers. The diameter of the zone of TCP solublization was measured and expressed in millimeters. The bacterial isolates positive for $\mathrm{P}$ solublization on Pikovskaya's agar medium were subjected to quantification of Pi released from TCP in broth medium. 


\section{Biochemical characterization of the PSB isolates}

The biochemical characterization of the isolates was carried out as per the procedures outlined by Cappuccino and Sherman in their $10^{\text {th }}$ edition of Microbiology: A Laboratory Manual. Catalase test, Oxidase test, Indole production test, Methyl red test, VogesProskauer (VP) test, Urea hydrolysis, Nitrate reduction test, Gelatin hydrolysis test, Starch hydrolysis, Casein hydrolysis and $\mathrm{H}_{2} \mathrm{~S}$ production test were performed.

\section{Isolation of potash mobilizing bacteria from rhizospheric soil of soybean}

One gram of rhizosphere soil was mixed thoroughly in $100 \mathrm{ml}$ sterile water and was processed following serial dilution agar plate technique (Aneja, 2003). A suitable dilutions $\left(10^{5}\right.$ and $\left.10^{6}\right)$ of both rhizosphere and rhizoplane solutions were plated on Alexandrov medium (Hu et al., 2006). The plates were incubated at room temperature $\left(30 \pm 1^{\circ} \mathrm{C}\right)$ for 3 days and the colonies exhibiting clear zones of solubilization of muscovite mica were selected purified, subcultured and maintained on the slants of Alexandrov medium for further use.

\section{Biochemical characterization of KMB isolates}

The biochemical characterizations of the isolates were carried out as per the procedures outlined by Bergey's Manual of Systematic Bacteriology 9th Edition (1993). Sugar utilization, Methyl red test, Voges-Proskauer (VP) test, Urea hydrolysis, Nitrate reduction test, Gelatin hydrolysis test, catalase test, starch hydrolysis, Casein hydrolysis and $\mathrm{H}_{2} \mathrm{~S}$ production test were performed.

\section{Quantitative estimation of ' $K$ ' solublization}

The isolates showing zone of solublization on Alexandrov agar medium were further examined for their ability to release $\mathrm{K}$ from broth media. The amount of $\mathrm{K}$ released from muscovite mica in the broth by the isolates was studied at 7, 15 and 20 days after incubation (DAI) under laboratory condition (Parmar et al., 2016).

\section{Preparation of consortium of Rhizobium, PSB and KMB on a selective medium}

Inoculum of Bradyrhizobium japonicum, Bacillus subtilis and Frateuria aurantia was prepared in selective medium MS Ш (Shete $e t$ al., 2019). The media was inoculated in 500 $\mathrm{ml}$ conical flask containing $150 \mathrm{ml}$ medium and incubated at $28 \pm 2^{\circ} \mathrm{C}$ under shaking at $100-150 \mathrm{rpm}$ for three days to give an optical density of 0.5 recorded at $535 \mathrm{~nm}$. Lignite powder used as carrier was sterilized at $121^{\circ} \mathrm{C}$ and $1.04 \mathrm{~kg} / \mathrm{cm}^{2}$ pressure for one hour and inoculated with broth cultures of Bradyrhizobium japonicum, Bacillus subtilis and Frateuria aurantia $(100 \mathrm{ml}$ per $500 \mathrm{~g}$ of lignite powder). Lignite powder based inoculum was incubated at $28 \pm 2^{\circ} \mathrm{C}$ for three days by adding $10 \%$ sugar solution to increase the population of respective microbe. Inoculum of Bradyrhizobium japonicum, Bacillus subtilis and Frateuria aurantia having cfu of $2 \times 10^{7}$ per gram of lignite powder were applied to soybean as seed coating.

\section{Field experiment}

A field experiment was conducted during kharif, 2019 in the field at College of Agriculture, Pune to study the effect of seed inoculation with consortium of Rhizobium, PSB and KMB on growth parameters, nutrient uptake and yield of soybean. The soybean variety Phule Sangam was used as a test crop. The experiment was laid out in randomized block design with three replications and nine treatments. 


\section{Treatment details}

The soybean seeds were treated before sowing as follows:

$\mathrm{T}_{1}$ : Consortium of Rhizobium, PSB and KMB

$\mathrm{T}_{2}$ : Consortium of Rhizobium, PSB and KMB $+100 \%$ RDF

$\mathrm{T}_{3}$ : Consortium of Rhizobium, PSB and KMB $+75 \% \mathrm{RDF}$

$\mathrm{T}_{4}$ : Consortium of Rhizobium, PSB and KMB $+50 \% \mathrm{RDF}$

$\mathrm{T}_{5}$ : Rhizobium $+75 \%$ recommended $\mathrm{N}+$ $100 \%$ recommended $\mathrm{P}_{2} \mathrm{O}_{5}$ and $\mathrm{K}_{2} \mathrm{O}$

$\mathrm{T}_{6}$ : PSB + 75\% recommended $\mathrm{P}_{2} \mathrm{O}_{5}+100 \%$ recommended $\mathrm{N}$ and $\mathrm{K}_{2} \mathrm{O}$

$\mathrm{T}_{7}: \mathrm{KMB}+75 \%$ recommended $\mathrm{K}_{2} \mathrm{O}+100 \%$ recommended $\mathrm{N}$ and $\mathrm{P}_{2} \mathrm{O}_{5}$

$\mathrm{T}_{8}: 100 \% \mathrm{RDF}$

$\mathrm{T}_{9}$ : Absolute control

The observations on germination (\%), shoot length $(\mathrm{cm})$, root length $(\mathrm{cm})$ and plant vigour index at 15 days after sowing, plant height $(\mathrm{cm})$, root length $(\mathrm{cm})$, dry weight of shoot $(\mathrm{g}$ plant $\left.^{-1}\right)$ and dry weight of root $\left(\mathrm{mg} \mathrm{plant}^{-1}\right)$ at flowering and harvest stage of the crop, number of branches, number of nodules and number of pods per plant, 1000 seed weight, NPK uptake $\left(\mathrm{kg} \mathrm{ha}^{-1}\right)$ and seed yield $\left(\mathrm{q} \mathrm{ha}^{-1}\right)$ of soybean were recorded. Plant vigour index was computed at 15 days after sowing using the formula: Plant vigour index $=$ Germination $\% \mathrm{x}$ [shoot length $(\mathrm{cm})+$ root length $(\mathrm{cm})]$. Nitrogen content of plant was estimated by following Modified Kjeldahl's process and accordingly $\mathrm{N}$ uptake $\left(\mathrm{kg} \mathrm{ha}^{-1}\right)$ was estimated as $\mathrm{N} \% \mathrm{x}$ total dry matter yield $\left(\mathrm{kg} \mathrm{ha}^{-1}\right) / 100$.

\section{Microbial count of Rhizobium, PSB and $\mathrm{KMB}$ at flowering stage of soybean}

Fresh root nodules of soybean at flowering stage were analyzed for rhizobial population on yeast extract mannitol agar media as described by Rajendran et al., (2008).
Moreover, rhizospheric soil samples at flowering stage of soybean were analyzed for microbial population of phosphate solubilizing bacteria (PSB) and potash mobilizing bacteria (KMB) using serial dilution of soil and agar plating method (Aneja, 2003). The PSB and KMB population was enumerated on Pikovskaya's media and Alexandrov's agar media, respectively, at $10^{6}$ dilutions. The plates were incubated at $28 \pm 2$ ${ }^{0} \mathrm{C}$ temperature for 72 hours and colonies were counted. The population was expressed as cfu $\mathrm{g}^{-1}$ soil.

\section{Statistical analysis}

The data recorded on various parameters was subjected to statistical analysis by following standard method of analysis of variance. The level of significance used in ' $F$ ' and ' $t$ ' tests was $\mathrm{P}=0.05$. Critical difference $(\mathrm{CD})$ values were calculated where the ' $F$ ' test was found significant (Panse and Sukhatme, 1985).

\section{Results and Discussion}

Isolation of nitrogen fixing, phosphate solubilizing and potash mobilizing bacteria

The isolation of Rhizobium from root nodule of soybean (var. Phule Sangam) was done using yeast extract mannitol agar medium. The isolation procedure was carried out for all the three samples and three isolates were obtained as RH-I, RH-II and RH-III. Moreover, isolation of phosphate solublizing bacteria on Pikovskaya's medium was carried out by serial dilution of soil and agar plating method (Aneja, 2003). The isolation procedure was carried out for all the three rhizosphere soil samples and the plates were observed for the appearance of bacterial colony showing clear zone of solublization of tricalcium phosphate purified (TCP) on Pikovskaya's medium. Three isolates were obtained as P-I, P-II and P-III. Furthermore, 
isolation of potash mobilizing bacteria was carried out on Alexandrov medium. The isolation procedure was carried out for all the three rhizosphere soil samples on Alexandrov medium (Hu et al., 2006). The plates were observed for the appearance of bacterial colony showing clear zone of solublization of insoluble potassium bearing mineral (mica). Three isolates were obtained as K-I, K-II and K-III.

\section{Nitrogen fixing ability of Rhizobium isolate}

All the three Rhizobium isolates of soybean alongwith MPKV strain (Bradyrhizobium japonicum) were subjected to know the nitrogen fixation by Microkjeldhal method (Table 1). The isolate $\mathrm{RH}-1$ fixed highest amount of nitrogen (148.65 $\mu \mathrm{g}$ of nitrogen $/ \mathrm{mg}$ of carbon used). This was followed by MPKV strain, RH-II and RH-III isolate (145.78, 129.76 and $121.84 \mu \mathrm{g}$ of nitrogen $/ \mathrm{mg}$ of carbon used, respectively). The results of the present investigation are in agreement with results of Hema and Savalgi (2017) who reported that isolate from maize GdM5 fixed about $142 \mu \mathrm{g}$ of nitrogen/mg of carbon used.

\section{Phosphate solubilizing ability of the PSB isolates}

All the three PSB isolates alongwith MPKV strain (Bacillus subtilis) were tested for their ability to solubilize inorganic phosphate both qualitatively and quantitatively and their results are presented in Table 2. Quick analysis of P-solubilization was carried out on Pikovskaya's agar medium. All the three isolates were able to form zone of $\mathrm{P}$ solubilization on the medium. The diameter of the zone of P-solubilization ranged from 3-6 $\mathrm{mm}$ in different isolates.

\section{Quantitative estimation of Pi released from TCP for bacterial isolates}

The amount of Pi released from tri-calcium phosphate by the PSB isolates along with
MPKV strain (Bacillus subtilis) in Pikovskaya's broth was estimated at 10 days after inoculation. The amount of Pi released from TCP by the isolates at 10 DAI ranged from 11.43 to 29.38 per cent (Table 2). The isolate P-I recorded highest P-solubilization $(29.38 \%)$ than the other isolates tested.

\section{Decrease in pH of medium during phosphate solubilization}

The decrease in $\mathrm{pH}$ of TCP broth from initially adjusted $\mathrm{pH}$ of 7.0 was also noted at 10 days after inoculation. The maximum reduction in $\mathrm{pH}$ of the medium i.e. $\mathrm{pH} 3.48$ was recorded by P-I isolate followed by MPKV strain (Bacillus subtilis), P-II and P-III isolates (3.50, 4.09 and 4.11, respectively) (Table 2). The decrease in $\mathrm{pH}$ of the medium with the amount of $\mathrm{Pi}$ released had positive correlation.

\section{Quantitative estimation of ' $K$ ' solubilisation of the KMB isolates}

The isolates showing zone of solubilization on Alexandrov agar medium were further examined for their ability to release ' $\mathrm{K}$ ' from broth media. The amount of ' $K$ ' released from muscovite mica in the broth by the isolates alongwith MPKV strain (Frateuria aurantia) were studied at 7, 15 and 20 days after incubation (DAI) in lab condition and found in the range of 6.49 to $40.81 \mu \mathrm{g} \mathrm{ml}^{-1}$ (Table $3)$. The results indicated that the amount of released ' $\mathrm{K}$ ' increased as the days of incubation increases and the highest amount of ' $\mathrm{K}$ ' present at 20 DAI. The maximum solubilization of muscovite mica was observed in K-I isolate (40.81 $\mu \mathrm{g} \mathrm{m} \mathrm{ml}^{-1}$ ) followed by MPKV strain (Frateuria aurantia) (39.25 $\left.\mu \mathrm{g} \mathrm{ml}^{-1}\right)$ at $20 \mathrm{DAI}$. The results of the present investigation are in agreement with the results of Parmar et al., (2016) who isolated 25 potassium solubilizing bacterial isolates from the rhizosphere of maize from various areas of Navsari district 
and tested quantitative estimation of ' $\mathrm{K}$ ' solubilisation of the highly efficient $\mathrm{KMB}$ isolates. He further reported the amount of ' $\mathrm{K}$ ' released from muscovite mica in the broth by the isolates in the range of 1.89 to $46.52 \mu \mathrm{g}$ $\mathrm{ml}^{-1}$.

On the basis of nitrogen fixing, phosphate solubilising and potash mobilizing ability, highly efficient nitrogen fixing Rhizobium isolate (RH-I), phosphate solubilising isolate (P-I) and potash mobilizing isolate (K-I) were further tested for different biochemical characterization.

\section{Biochemical characterization of Rhizobium, PSB and KMB isolate}

The highly efficient nitrogen fixing rhizobial isolate (RH-I) was tested for different biochemical characters viz., gram staining, motility test, gelatin hydrolysis, catalase test, oxidase test, indole production test, starch hydrolysis, $\mathrm{H}_{2} \mathrm{~S}$ production, Voges- Proskaeur test and growth on different carbon sources (Table 4). The cells of nitrogen fixing rhizobial isolate were rod shape, motile and gram negative in reaction. The nitrogen fixing rhizobial isolate was positive for catalase test, oxidase test, indole production test, starch hydrolysis, $\mathrm{H}_{2} \mathrm{~S}$ production and VogesProskaeur test but was negative for gelatin hydrolysis. Glucose, sucrose and mannitol were used as a sole carbon source for growth by the nitrogen fixing rhizobial isolate. Based on biochemical and physiological characterization, the nitrogen fixing rhizobial isolate was identified as Bradyrhizobium japonicum. The results of the present investigation are in conformity with results of Jadhav (2013) who isolated rhizobia from root nodule of soybean cultivated in Latur area and further characterized these isolates biochemically for specific characters of Bradyrhizobium japonicum according to Burgey's Manual of Systematic Bacteriology.
All the isolates were positive for most of characters specific for Bradyrhizobium japonicum. Further all isolates tested negative for gelatin hydrolysis.

The highly efficient phosphate solubilizing bacterial isolate (P-I) was tested for different biochemical characters viz., gram staining, motility test, gelatin hydrolysis, catalase test, oxidase test, starch hydrolysis, $\mathrm{H}_{2} \mathrm{~S}$ production and Voges- Proskaeur test (Table 4). The cells of phosphate solubilizing bacterial isolate were rod shape, motile and gram positive in reaction. The phosphate solubilizing bacterial isolate was positive for gelatin hydrolysis, catalase test, starch hydrolysis and Voges- Proskaeur test but was negative for oxidase test and $\mathrm{H}_{2} \mathrm{~S}$ production. Based on biochemical and physiological characterization (Claus and Berkeley, 1986), the phosphate solubilizing bacterial isolate was identified as Bacillus subtilis. The highly efficient potash mobilizing bacterial isolate (K-I) was tested for different biochemical characters viz., gram staining, motility test, methyl red test, Voges-Proskauer (VP) test, urea hydrolysis, nitrate reduction test, gelatine hydrolysis test, catalase test, starch hydrolysis, casein hydrolysis, $\mathrm{H}_{2} \mathrm{~S}$ production test and growth on different carbon sources (Table 4). The potash mobilizing bacterial isolate was rod shape, motile and gram negative in reaction. The potash mobilizing bacterial isolate was positive for gelatin hydrolysis, catalase test, starch hydrolysis, urea hydrolysis, casein hydrolysis test, nitrate reduction test and methyl red test but was negative for $\mathrm{H}_{2} \mathrm{~S}$ production and VogesProskaeur test. Sucrose, mannitol and maltose were used as a sole carbon source for growth by the potash mobilizing bacterial isolates. Based on biochemical and physiological characterization (Parmar et al., 2016), the potash mobilizing bacterial isolate was identified as Frateuria aurantia. 
Growth of Rhizobium, PSB and KMB on different culture media

Broth of each culture media viz., M I, M II, M III, M IV and M V were inoculated with efficient strains of Rhizobium, PSB and Potash mobilizing bacteria separately as well as in consortia and kept for incubation at $28 \pm 2{ }^{\circ} \mathrm{C}$ for 5 days. The data presented in Table 5 revealed that the maximum growth of Rhizobium, PSB and potash mobilizing bacteria was found on MS III culture media. Moreover, Rhizobium, PSB and KMB were found to be compatible with each other on MS III culture media. Singh et al., (2014) reported maximum growth of rhizobia in media containing $12.5 \mathrm{~g} \mathrm{l}^{-1}$ sucrose at $29.4^{\circ} \mathrm{C}$ for 7 days. Further, Kucuk et al., (2006) reported that Rhizobium strains were able to utilize glucose and sucrose more efficiently than normal YEM medium. Moreover, Sagervanshi et al., (2014) studied the effect of different nitrogen sources viz., ammonium sulphate, casein, sodium nitrate and urea and found best optimized source was ammonium sulphate for the maximum ' $\mathrm{P}$ ' solubilisation. Furthermore, Sugumaran and Janarthanam (2007) reported that B. mucilaginosus isolated from soil, rock and mineral samples recorded $4.29 \mathrm{mg} \mathrm{l}^{-1}$ release of potassium in media supplemented with muscovite mica. Results of the present investigation are in agreement with results of these researchers.

Microbial count of Rhizobium, PSB and $\mathrm{KMB}$ in a consortium on diverse culture media

The data on microbial count of Rhizobium, PSB and potash mobilizing bacteria is presented in Table 6. Among all the culture media, MS III culture medium recorded maximum count of Rhizobium, PSB and $\mathrm{KMB}\left(12 \times 10^{7}, 7 \times 10^{7}\right.$ and $9 \times 10^{7} \mathrm{cfu} \mathrm{g}^{-1}$, respectively).
Preparation of consortium of Rhizobium, PSB and KMB

Inoculum of Rhizobium (Bradyrhizobium japonicum), PSB (Bacillus subtilis) and KMB (Frateuria aurantia) was prepared in a selective medium MS Ш. The media was inoculated in $500 \mathrm{ml}$ conical flask containing $150 \mathrm{ml}$ medium and incubated at $28 \pm 2^{\circ} \mathrm{C}$ under shaking at 100-150 rpm for three days to give an optical density of 0.5 recorded at $535 \mathrm{~nm}$. Lignite powder used as carrier was sterilized at $121^{\circ} \mathrm{C}$ and $1.04 \mathrm{~kg} / \mathrm{cm}^{2}$ pressure for one hour and inoculated with broth cultures of Bradyrhizobium japonicum, Bacillus subtilis and Frateuria aurantia (100 $\mathrm{ml}$ in $500 \mathrm{~g}$ lignite powder). Lignite powder based inoculum was incubated at $28 \pm 2{ }^{\circ} \mathrm{C}$ for three days by adding $10 \%$ sugar solution to increase the population of the respective microbes. The inoculum of Bradyrhizobium japonicum, Bacillus subtilis and Frateuria aurantia having $2 \times 10^{7} \mathrm{cfu}^{-1}$ of lignite powder was applied to soybean as seed coating.

Inoculation effect of consortium of Rhizobium, PSB and KMB on growth parameters and yield of soybean

The results in respect of growth and yield attributing characters of soybean are presented in Table 7 and 8 . The results of the present investigation revealed that among the different inoculation treatments, $\mathrm{T}_{3}$ i.e. seed inoculation with consortium of Rhizobium, PSB and $\mathrm{KMB}+75 \% \mathrm{RDF}$ was found to be the most effective as it recorded significantly highest germination (97.34\%), plant vigour index (3370.47) at 15 days after sowing, plant height $(33.47 \mathrm{~cm}$ and $44.83 \mathrm{~cm})$, root length $(13.45 \mathrm{~cm}$ and $19.47 \mathrm{~cm})$, dry weight of shoot (7.65 $\mathrm{g} \mathrm{plant}^{-1}$ and $8.90 \mathrm{~g} \mathrm{plant}^{-1}$ ) and dry weight of root $\left(905.33 \mathrm{mg}\right.$ plant $^{-1}$ and $978 \mathrm{mg}$ plant $^{-1}$ ) at flowering and harvest stage of the crop, number of branches (5.67 plant $\left.^{-1}\right)$, 
number of nodules (20.93 plant $\left.^{-1}\right)$, number of pods (55.23 plant $\left.^{-1}\right), 1000$ seed weight $(125.36 \mathrm{~g})$ and seed yield $\left(19.48 \mathrm{q} \mathrm{ha}^{-1}\right)$ of soybean, however it was statistically at par with the treatment $\mathbf{T}_{2}$ i.e. seed inoculation with consortium $+100 \%$ RDF for growth parameters and seed yield of soybean. Bansal (2009) reported that presowing inoculation of mungbean seeds with different inoculants (Rhizobium, PGPR and PSB) alone or in combination, significantly increased the plant height, root length, dry matter production, number of nodules/plant, 1000 seed weight, nutrient uptake and seed yield over uninoculated control. Moreover, Qureshi et al., (2011), Argaw (2012) and Tarafder et al., (2016) reported increased growth parameters, nutrient uptake and seed yield in different legume crops due to seed inoculation of Rhizobium, PGPR and PSB alone or in combination. Results of the present investigation are in agreement with results of these researchers.

Table.1 Nitrogen fixing ability of Rhizobium isolate of soybean by Microkjeldhal method

\begin{tabular}{|c|c|c|}
\hline Sr. No. & Rhizobium isolate & $\begin{array}{c}\text { Nitrogen fixing ability } \\
\text { ( } \mu \mathrm{g} \text { of Nitrogen/mg of Carbon) }\end{array}$ \\
\hline 1. & RH-I & 148.65 \\
\hline 2. & RH-II & 129.76 \\
\hline 3. & RH-III & 121.84 \\
\hline 4. & MPKV strain (Bradyrhizobium japonicum) & 145.78 \\
\hline
\end{tabular}

Table.2 Zone of P solubilization on Pikovskaya's agar and per cent Pi released from TCP broth by the PSB isolates

\begin{tabular}{|c|l|c|c|c|}
\hline $\begin{array}{c}\text { Sr. } \\
\text { No. }\end{array}$ & PSB Isolate & $\begin{array}{c}\text { Zone of P } \\
\text { solubilization on } \\
\text { TCP }(\mathbf{m m})\end{array}$ & $\begin{array}{c}\text { \% Pi released } \\
\text { from TCP after } \\
\mathbf{1 0} \text { days }\end{array}$ & $\begin{array}{c}\text { Decrease in } \mathbf{~ p H ~ o f ~} \\
\text { medium (from initial } \mathbf{~ p H} \\
\mathbf{7 . 0}) \text { after 10 days }\end{array}$ \\
\hline $\mathbf{1}$ & P-I & 6.0 & 29.38 & 3.48 \\
\hline $\mathbf{2}$ & P-II & 5.0 & 13.23 & 4.09 \\
\hline $\mathbf{3}$ & P-III & 3.0 & 11.43 & 4.11 \\
\hline $\mathbf{4 .}$ & MPKV strain & 6.0 & 28.35 & 3.50 \\
\hline & (Bacillus subtilis) & & & \\
\hline
\end{tabular}

Table.3 Solubilization of muscovite mica by the KMB isolates

\begin{tabular}{|c|l|c|c|c|}
\hline Sr. No. & KMB isolate & 7 DAI $\left(\mathbf{\mu g ~ m l}^{-\mathbf{1}}\right)$ & $\mathbf{1 5} \mathbf{D A I}\left(\boldsymbol{\mu g} \mathbf{~ m l}^{-\mathbf{1}}\right)$ & $\mathbf{2 0} \mathbf{D A I}\left(\left(\mathbf{\mu g} \mathbf{~ m l}^{-\mathbf{1}}\right)\right.$ \\
\hline $\mathbf{1 .}$ & K-I & 24.56 & 37.26 & 40.81 \\
\hline $\mathbf{2 .}$ & K-II & 12.50 & 21.58 & 33.75 \\
\hline $\mathbf{3 .}$ & K-III & 6.49 & 19.60 & 30.42 \\
\hline $\mathbf{4 .}$ & $\begin{array}{l}\text { MPKV strain } \\
\text { (Frateuria aurantia) }\end{array}$ & 23.25 & 35.10 & 39.25 \\
\hline
\end{tabular}


Table.4 Selective biochemical tests of nitrogen fixing, phosphate solubilizing and potash mobilizing bacterial isolate

\begin{tabular}{|c|c|c|c|c|}
\hline $\begin{array}{l}\text { Sr. } \\
\text { No. }\end{array}$ & Biochemical tests & $\begin{array}{l}\text { Rhizobium isolate } \\
\text { (RH-I) }\end{array}$ & $\begin{array}{l}\text { PSB isolate } \\
\text { (P-I) }\end{array}$ & $\begin{array}{l}\text { KMB isolate } \\
(\mathrm{K}-\mathrm{I})\end{array}$ \\
\hline 1. & Cell shape & Rod shape & Rod shape & Rod shape \\
\hline 2. & Gram reaction & Gram negative & Gram positive & Gram negative \\
\hline 3. & Motility & + & + & + \\
\hline 4. & Gelatin hydrolysis & - & + & + \\
\hline 5. & Catalase test & + & + & + \\
\hline 6. & Oxidase test & + & - & \\
\hline 7. & Indole production test & + & & \\
\hline 8. & Starch hydrolysis & + & + & + \\
\hline 9. & $\mathrm{H} 2 \mathrm{~S}$ production & + & - & - \\
\hline 10. & Voges- Proskaeur test & + & + & - \\
\hline 11. & Urea hydrolysis & & & + \\
\hline 12. & Caesin hydrolysis test & & & + \\
\hline 13. & Nitrate reduction test & & & + \\
\hline 14. & Methyl red test & & & + \\
\hline \multirow{5}{*}{15.} & Growth on carbon sources & & & \\
\hline & a) Glucose & + & & \\
\hline & b) Sucrose & + & & + \\
\hline & c) Mannitol & + & & + \\
\hline & d) Maltose & & & + \\
\hline
\end{tabular}

Table.5 Growth of Rhizobium, PSB and KMB on different culture media

\begin{tabular}{|c|l|c|c|c|}
\hline Sr. No. & Culture media & Rhizobium & PSB & KMB \\
\hline 1. & MS I & + & + & + \\
\hline $\mathbf{2 .}$ & MS II & ++ & + & - \\
\hline 3. & MS III & +++ & +++ & +++ \\
\hline $\mathbf{4 .}$ & MS IV & + & - & - \\
\hline $\mathbf{5 .}$ & MS V & - & + & + \\
\hline
\end{tabular}

Table.6 Microbial count of Rhizobium, PSB and KMB in a consortium on different culture media

\begin{tabular}{|c|l|c|c|c|}
\hline $\begin{array}{c}\text { Sr. } \\
\text { No. }\end{array}$ & Culture media & $\begin{array}{c}\text { Rhizobium } \\
\left(\boldsymbol{c f u} \mathbf{g}^{-1}\right)\end{array}$ & $\begin{array}{c}\text { PSB } \\
\left(\boldsymbol{c f u} \mathbf{g}^{-\mathbf{1}}\right)\end{array}$ & $\begin{array}{c}\text { KMB } \\
\left(\boldsymbol{c f u} \mathbf{~ g}^{-\mathbf{1}}\right)\end{array}$ \\
\hline $\mathbf{1 .}$ & MS I & $1 \times 10^{3}$ & $1 \times 10^{3}$ & $1 \times 10^{3}$ \\
\hline $\mathbf{2 .}$ & MS II & $1 \times 10^{5}$ & $1 \times 10^{3}$ & - \\
\hline 3. & MS III & $12 \times 10^{7}$ & $7 \times 10^{7}$ & $9 \times 10^{7}$ \\
\hline $\mathbf{4 .}$ & MS IV & $1 \times 10^{3}$ & - & $1 \times 10^{7}$ \\
\hline 5. & MS V & - & $1 \times 10^{3}$ & $1 \times 10^{7}$ \\
\hline
\end{tabular}


Table 7 Inoculation effect of consortium of Rhizobium, PSB and KMB on growth parameters of soybean

\begin{tabular}{|c|c|c|c|c|c|c|c|c|c|}
\hline \multirow[t]{2}{*}{$\begin{array}{l}\text { Tr. } \\
\text { No }\end{array}$} & \multirow[t]{2}{*}{ Treatment details } & \multirow[t]{2}{*}{$\begin{array}{l}\text { Germination } \\
\qquad(\%)\end{array}$} & \multirow{2}{*}{$\begin{array}{l}\text { Plant } \\
\text { vigour } \\
\text { index }\end{array}$} & \multicolumn{2}{|c|}{ Plant height $(\mathrm{cm})$} & \multicolumn{2}{|c|}{ Root length (cm) } & \multicolumn{2}{|c|}{$\begin{array}{c}\text { Dry weight of shoot } \\
\left(\text { g plant }^{-1}\right)\end{array}$} \\
\hline & & & & Flowering & Harvest & Flowering & Harvest & Flowering & Harvest \\
\hline $\mathbf{T}_{1}$ & $\begin{array}{l}\text { Consortium of Rhizobium, PSB } \\
\text { and KMB }\end{array}$ & 93.21 & $\begin{array}{c}2840.5 \\
2\end{array}$ & 31.47 & 42.60 & 12.02 & 16.62 & 6.49 & 7.82 \\
\hline $\mathbf{T}_{2}$ & $\begin{array}{l}\text { Consortium of Rhizobium, PSB } \\
\text { and KMB }+100 \% \text { RDF }\end{array}$ & 96.60 & $\begin{array}{c}3132.8 \\
2\end{array}$ & 32.50 & 43.72 & 12.62 & 18.27 & 7.29 & 8.41 \\
\hline $\mathbf{T}_{\mathbf{3}}$ & $\begin{array}{l}\text { Consortium of Rhizobium, PSB } \\
\text { and KMB }+75 \% \text { RDF }\end{array}$ & 97.34 & $\begin{array}{c}3370.4 \\
7\end{array}$ & 33.47 & 44.83 & 13.45 & 19.47 & 7.65 & 8.90 \\
\hline $\mathbf{T}_{4}$ & $\begin{array}{l}\text { Consortium of Rhizobium, PSB } \\
\text { and } \mathrm{KMB}+50 \% \mathrm{RDF}\end{array}$ & 95.06 & $\begin{array}{c}2957.8 \\
5\end{array}$ & 31.53 & 42.67 & 12.10 & 16.80 & 6.83 & 8.02 \\
\hline $\mathbf{T}_{5}$ & $\begin{array}{l}\text { Rhizobium }+75 \% \\
\text { recommended } \mathrm{N}+100 \% \\
\text { recommended P2O5 \& K2O }\end{array}$ & 92.89 & $\begin{array}{c}2867.9 \\
0\end{array}$ & 31.37 & 41.87 & 11.90 & 16.42 & 5.95 & 7.22 \\
\hline $\mathbf{T}_{6}$ & $\begin{array}{l}\mathrm{PSB}+75 \% \text { recommended } \\
\mathrm{P} 2 \mathrm{O} 5+100 \% \text { recommended } \mathrm{N} \\
\text { and } \mathrm{K} 2 \mathrm{O}\end{array}$ & 91.35 & $\begin{array}{c}2776.7 \\
7\end{array}$ & 30.87 & 41.58 & 11.75 & 16.28 & 5.62 & 6.97 \\
\hline $\mathbf{T}_{7}$ & $\begin{array}{l}\mathrm{KMB}+75 \% \text { recommended } \\
\mathrm{K} 2 \mathrm{O}+100 \% \text { recommended } \mathrm{N} \\
\text { and } \mathrm{P} 2 \mathrm{O} 5\end{array}$ & 91.00 & $\begin{array}{c}2665.2 \\
5\end{array}$ & 30.78 & 41.22 & 11.60 & 15.87 & 5.50 & 6.48 \\
\hline $\mathbf{T}_{8}$ & $100 \% \mathrm{RDF}$ & 91.76 & $\begin{array}{c}2769.1 \\
4\end{array}$ & 32.20 & 42.87 & 12.25 & 17.93 & 6.85 & 8.14 \\
\hline $\mathbf{T}_{9}$ & Uninoculated control & 85.18 & $\begin{array}{c}2257.6 \\
4\end{array}$ & 27.87 & 39.33 & 9.20 & 13.38 & 3.95 & 5.49 \\
\hline & S.E. & 2.12 & 82.47 & 0.34 & 0.42 & 0.29 & 0.47 & 0.19 & 0.21 \\
\hline & C.D.at $5 \%$ & 6.35 & 247.23 & 1.02 & 1.27 & 0.85 & 1.40 & 0.58 & 0.64 \\
\hline & C.V. & 3.96 & 5.01 & 1.88 & 1.73 & 4.16 & 4.81 & 5.34 & 4.96 \\
\hline
\end{tabular}

$\mathrm{PSB}=$ Phosphate solubilizing bacteria,

$\mathrm{KMB}=$ Potash mobilizing bacteria 
Table.8 Inoculation effect of consortium of Rhizobium, PSB and KMB on growth and yield attributing characters of soybean

\begin{tabular}{|c|c|c|c|c|c|c|c|c|}
\hline \multirow[t]{2}{*}{$\begin{array}{l}\text { Tr. } \\
\text { No }\end{array}$} & \multirow[t]{2}{*}{ Treatment details } & \multicolumn{2}{|c|}{$\begin{array}{l}\text { Dry weight of root } \\
\left(\mathrm{g} \mathrm{plant}^{-1}\right)\end{array}$} & \multirow{2}{*}{$\begin{array}{l}\text { Number of } \\
\text { branches } \\
\text { plant }^{-1}\end{array}$} & \multirow{2}{*}{$\begin{array}{l}\text { Number of } \\
\text { nodules } \\
\text { plant }^{-1}\end{array}$} & \multirow{2}{*}{$\begin{array}{l}\text { Number of } \\
\text { pods } \\
\text { plant }^{-1}\end{array}$} & \multirow[t]{2}{*}{$\begin{array}{l}1000 \text { seed } \\
\text { weight }(g)\end{array}$} & \multirow[t]{2}{*}{$\begin{array}{l}\text { Seed yield } \\
\left(\mathrm{q} \mathrm{ha} \mathrm{ha}^{-1}\right)\end{array}$} \\
\hline & & Flowering & Harvest & & & & & \\
\hline $\mathbf{T}_{1}$ & $\begin{array}{l}\text { Consortium of Rhizobium, PSB } \\
\text { and KMB }\end{array}$ & 803.33 & 879.67 & 7.00 & 18.20 & 49.97 & 120.00 & 17.04 \\
\hline $\mathbf{T}_{2}$ & $\begin{array}{l}\text { Consortium of Rhizobium, PSB } \\
\text { and KMB }+100 \% \text { RDF }\end{array}$ & 850.00 & 918.33 & 7.13 & 19.85 & 53.20 & 123.04 & 18.44 \\
\hline $\mathbf{T}_{\mathbf{3}}$ & $\begin{array}{l}\text { Consortium of Rhizobium, PSB } \\
\text { and KMB }+75 \% \text { RDF }\end{array}$ & 905.33 & 978.00 & 7.67 & 20.93 & 55.23 & 125.36 & 19.48 \\
\hline $\mathbf{T}_{4}$ & $\begin{array}{l}\text { Consortium of Rhizobium, PSB } \\
\text { and } \mathrm{KMB}+50 \% \mathrm{RDF}\end{array}$ & 808.33 & 885.67 & 7.03 & 18.33 & 50.27 & 120.18 & 17.18 \\
\hline $\mathbf{T}_{5}$ & $\begin{array}{l}\text { Rhizobium }+75 \% \\
\text { recommended } \mathrm{N}+100 \% \\
\text { recommended } \mathrm{P} 2 \mathrm{O} 5 \& \mathrm{~K} 2 \mathrm{O}\end{array}$ & 788.67 & 853.00 & 6.97 & 18.13 & 48.87 & 119.76 & 16.62 \\
\hline $\mathbf{T}_{6}$ & $\begin{array}{l}\mathrm{PSB}+75 \% \text { recommended } \\
\mathrm{P} 2 \mathrm{O} 5+100 \% \text { recommended } \mathrm{N} \\
\text { and } \mathrm{K} 2 \mathrm{O}\end{array}$ & 767.00 & 835.00 & 6.70 & 17.13 & 48.20 & 118.89 & 16.33 \\
\hline $\mathbf{T}_{7}$ & $\begin{array}{l}\mathrm{KMB}+75 \% \text { recommended } \\
\mathrm{K} 2 \mathrm{O}+100 \% \text { recommended } \mathrm{N} \\
\text { and } \mathrm{P} 2 \mathrm{O} 5\end{array}$ & 742.33 & 829.67 & 6.63 & 16.83 & 48.00 & 117.27 & 16.21 \\
\hline $\mathbf{T}_{8}$ & $100 \% \mathrm{RDF}$ & 812.33 & 895.33 & 7.07 & 14.37 & 51.30 & 121.86 & 17.35 \\
\hline \multirow[t]{4}{*}{$\mathbf{T}_{9}$} & Uninoculated control & 377.00 & 412.00 & 5.60 & 9.77 & 30.33 & 109.74 & 14.62 \\
\hline & S.E. & 25.97 & 25.05 & 0.19 & 0.37 & 0.79 & 0.83 & 0.70 \\
\hline & C.D.at $5 \%$ & 77.85 & 75.10 & 0.58 & 1.10 & 2.37 & 2.50 & 2.09 \\
\hline & C.V. & 5.91 & 5.22 & 6.88 & 3.74 & 2.83 & 1.21 & 7.08 \\
\hline
\end{tabular}


Table.9 Inoculation effect of consortium of Rhizobium, PSB and KMB on available nutrients and nutrient uptake at harvest and microbial population at flowering stage of soybean

\begin{tabular}{|c|c|c|c|c|c|c|c|c|c|c|}
\hline \multirow[t]{2}{*}{ Tr. No } & \multirow[t]{2}{*}{ Treatment details } & \multicolumn{3}{|c|}{ Available nutrients $\left(\mathrm{kg} \mathrm{ha}^{-1}\right)$} & \multicolumn{3}{|c|}{ Nutrient uptake $\left(\mathrm{kg} \mathrm{ha}^{-1}\right)$} & \multicolumn{3}{|c|}{$\begin{array}{l}\text { Microbial population at } \\
\text { flowering }\left(\times \mathbf{1 0}^{6}\right)\end{array}$} \\
\hline & & $\mathrm{N}$ & $\mathrm{P}_{2} \mathrm{O}_{5}$ & $\mathrm{~K}_{2} \mathrm{O}$ & $\mathrm{N}$ & $\mathrm{P}_{2} \mathrm{O}_{5}$ & $\mathrm{~K}_{2} \mathrm{O}$ & $\begin{array}{c}\text { Rhizobiu } \\
m\end{array}$ & PSB & KMB \\
\hline $\mathbf{T}_{1}$ & $\begin{array}{l}\text { Consortium of Rhizobium, PSB } \\
\text { and KMB }\end{array}$ & 168.00 & 16.27 & 70.31 & 25.88 & 4.65 & 13.55 & 29.63 & 22.21 & 19.00 \\
\hline $\mathbf{T}_{2}$ & $\begin{array}{l}\text { Consortium of Rhizobium, PSB } \\
\text { and KMB }+100 \% \text { RDF }\end{array}$ & 197.11 & 22.08 & 100.22 & 43.89 & 10.52 & 20.41 & 35.76 & 32.21 & 29.21 \\
\hline $\mathbf{T}_{3}$ & $\begin{array}{l}\text { Consortium of Rhizobium, PSB } \\
\text { and } \mathrm{KMB}+75 \% \mathrm{RDF}\end{array}$ & 202.67 & 26.03 & 104.37 & 48.56 & 12.10 & 22.67 & 39.44 & 35.47 & 31.87 \\
\hline $\mathbf{T}_{4}$ & $\begin{array}{l}\text { Consortium of Rhizobium, PSB } \\
\text { and KMB }+50 \% \text { RDF }\end{array}$ & 181.67 & 21.13 & 84.78 & 39.11 & 9.89 & 18.76 & 34.21 & 31.34 & 28.10 \\
\hline $\mathbf{T}_{5}$ & $\begin{array}{l}\text { Rhizobium }+75 \% \\
\text { recommended } \mathrm{N}+100 \% \\
\text { recommended } \mathrm{P} 2 \mathrm{O} 5 \& \mathrm{~K} 2 \mathrm{O}\end{array}$ & 175.33 & 16.18 & 78.55 & 40.12 & 8.45 & 17.29 & 28.74 & 15.42 & 11.34 \\
\hline $\mathbf{T}_{6}$ & $\begin{array}{l}\mathrm{PSB}+75 \% \text { recommended } \\
\mathrm{P} 2 \mathrm{O} 5+100 \% \text { recommended } \mathrm{N} \\
\text { and } \mathrm{K} 2 \mathrm{O}\end{array}$ & 171.50 & 18.58 & 74.70 & 39.61 & 10.21 & 19.33 & 20.57 & 24.22 & 16.11 \\
\hline $\mathbf{T}_{7}$ & $\begin{array}{l}\mathrm{KMB}+75 \% \text { recommended } \\
\mathrm{K} 2 \mathrm{O}+100 \% \text { recommended } \mathrm{N} \\
\text { and } \mathrm{P} 2 \mathrm{O} 5\end{array}$ & 164.81 & 16.11 & 67.18 & 38.51 & 9.35 & 20.03 & 18.65 & 21.37 & 18.24 \\
\hline $\mathbf{T}_{8}$ & $100 \% \mathrm{RDF}$ & 172.00 & 20.21 & 75.11 & 38.12 & 8.12 & 17.22 & 10.12 & 11.76 & 9.65 \\
\hline $\mathbf{T}_{9}$ & Uninoculated control & 156.67 & 12.82 & 59.26 & 20.31 & 4.11 & 13.27 & 4.55 & 6.11 & 3.76 \\
\hline & S.E. & 2.39 & 2.58 & 1.46 & 1.71 & 0.96 & 0.85 & 3.22 & 4.07 & 4.03 \\
\hline & C.D.at $5 \%$ & 7.18 & 7.79 & 4.42 & 5.19 & 2.89 & 2.66 & 9.74 & 12.30 & 12.18 \\
\hline
\end{tabular}


Inoculation effect of consortium of Rhizobium, PSB and KMB on available NPK and nutrient uptake after harvest of soybean

The results in respect of available NPK and nutrient uptake after harvest of soybean are presented in Table 9. The results of the present investigation revealed that among the different inoculation treatments, $T_{3}$ (consortium $+75 \% \quad \mathrm{RDF}$ ) recorded significantly highest available NPK (202.67, 26.03 and $104.37 \mathrm{~kg} \mathrm{ha}^{-1}$, respectively) and nutrient uptake $(48.56,12.10$ and $22.67 \mathrm{~kg}$ ha 1 , respectively) over rest of the treatments, however it was statistically at par with $\mathrm{T}_{2}$ (consortium $+100 \%$ RDF) for available NPK $\left(197.11,22.08\right.$ and $100.22 \mathrm{~kg} \mathrm{ha}{ }^{-1}$, respectively) and nutrient uptake (43.89, 10.52 and $20.41 \mathrm{~kg} \mathrm{ha}^{-1}$, respectively) by soybean at harvest. Increased available soil nutrients and nutrient uptake after harvest due to inoculation of Rhizobium, PGPR and PSB individually or in combination have been reported by several researchers in different legume crops (Bansal, 2009; Qureshi et al., 2011; Argaw, 2012; Tarafder et al., 2016 and Shete et al., 2019). Results of the present investigation are in agreement with these researchers.

Inoculation effect of consortium on microbial population of Rhizobium, PSB and $\mathrm{KMB}$ at flowering stage of soybean

At flowering stage, fresh root nodules of soybean were analyzed for rhizobial population and soil samples were analyzed for microbial population of phosphate solubilizing bacteria (PSB) and potash mobilizing bacteria (KMB) and data was analyzed and presented in Table 9. Among different inoculation treatments, $\mathrm{T}_{3}$ (consortium $+75 \% \mathrm{RDF}$ ) recorded significantly highest population of Rhizobium, PSB and KMB (59.44, 55.47 and $51.87 \times 10^{6}$ cfu g $^{-1}$ soil, respectively) at flowering stage of soybean and was found statistically at par with the treatment $\mathrm{T}_{2}$ (Consortium $+100 \%$ RDF) for microbial population of Rhizobium, PSB and KMB (55.76, 52.21 and 49.21 x $10^{6}$ $\mathrm{cfu} \mathrm{g}^{-1}$ soil, respectively). These results are in agreement with the results of Cao et al., (2016) who reported that the application of rhizobial inoculant and/or PSB inoculant to soybean significantly increased the population of Rhizobium and PSB at flowering stage of soybean. Moreover, Shete et al., (2019) reported that inoculation of mungbean with Rhizobium, PSB and KMB contributed to the increase in their population at flowering stages of crops and the counts were higher in inoculated treatments compared to uninoculated control. Results of the present investigation are in conformity with the results of these scientists.

From the present investigation it can be concluded that seed inoculation with consortium of Rhizobium, PSB and $\mathrm{KMB}+$ $75 \%$ RDF was found to be the most beneficial for getting higher seed yield of soybean with $25 \%$ saving of nitrogen, phosphorus and potassium dose of chemical fertilizers to soybean.

\section{Acknowledgement}

The authors express their sincere thanks and gratitude to the Head, Department of Plant Pathology and Agricultural Microbiology, College of Agriculture, Pune for extending research facilities and financial support for conducting the present study.

\section{References}

Abaidoo, R.C., Keyser, H.H., Singleton, P.W., Dashiell, K.E. and Sanginga, N. 2007. Population size, distribution, and symbiotic characteristics of indigenous Bradyrhizobium spp. that nodulate TGx 
soybean genotypes in Africa. App. Soil Ecol. 35: 57-67.

Aneja, K.R. 2003. Experiments in Microbiology, Plant Pathology and Biotechnology. New Age International Publishers, New Delhi, India. pp. 157161.

Argaw, A. 2012. Evaluation of Coinoculation of Bradyrhizobium japonicum and Phosphate Solubilizing Pseudomonas spp. Effect on Soybean (Glyceine max L. (Merr.)) in Assossa Area. J. Agric. Sci. Tech. 14: 213-224.

Bansal, R.K. 2009. Synergistic effect of Rhizobium, PSB and PGPR on nodulation and grain yield of mung bean. J. Food Legumes. 22(1): 37-39.

Bansal, R.K. 2015. Synergistic effect of Rhizobium, PSB and PGPR on nodulation and grain yield of mungbean. Int. J. Agric. Biol. 15: 5568.

Cao, N.D., Duong, B.S., Nguyen, B.T. and Phan, V.H.L. 2016. Effects of rhizobia and phosphate-solubilizing Bacteria on soybean (glycine $\max$ 1. Merr.) Cultivated on Ferralsols of daklak province, Vietnam. World J. Pharma. \& Pharmaceutical Sci. 5(4): 318-333.

Cappuccino, J.G. and Sherman, N. 1987. Microbiology A Laboratory Manual. $2^{\text {nd }}$ Ed. The Benjamin/Cummins Publishing Co., USA., 458p.

Claus, D. and Berkeley, R.C.W. 1986. Genus Bacillus cohn 1872. In: Bergy's Manual of Systematic Bacteriology, (Sneath, P.H.A., ed.), Williams and Wilkins Co., Baltimore. 2: 1105-1140.

Ganesan, P. and Gnanamanickam, S.S. 1987. Biological control of Sclerotium rolfsii sacc. In peanut by inoculation with Pseudomonas fluorescens. Soil Biol. Biochem. 19(1): 35-38.

Hema, C. Rao and Savalgi, V.P. 2017. Isolation and screening of nitrogen fixing endophytic bacterium
Gluconacetobacter diazotrophicus GdS25. Int. J. Curr. Microbiol. App. Sci. 6(3): 1364-1373.

Hu, X.F., Chen, J. and Guo, J.F. 2006. Two phosphate and potassium solubilizing bacteria isolated from Tiannu mountain, Zhejiang, China. World J. Microbiol. Biotech. 22: 983-990.

Javaid, A. 2009. Growth, nodulation and yield of black gram [Vigna mungo (L.) Hepper] as influenced by biofertilizers and soil amendments. Afr. $J$. Biotechnol. 8: 5711-5717.

Kucuk, C., Kivanc, M. and Kinaci, E. 2006. Characterization of Rhizobium sp. isolated from Bean. Turkey J. Biol. 30: 127-132.

Panse, V.S. and Sukhatme, P.V. 1985. Statistical Methods for Agricultural Workers. ICAR Publ., New Delhi, pp. 152-155.

Parmar, K.B., Mehta, B.P. and Kunt, M.D. 2016. Isolation, characterization and identification of potassium solubilizing bacteria from rhizosphere soil of maize (Zea mays). Int. J. Sci. Environ. Tech. 5(5): 3030-3037.

Qureshi, M.A., Shair, M.A., Iqbal, A., Ahtar, N. and Khan, A. 2011. Co-inoculation of phosphate solubilizing bactria and rhizobia for improving growth and yield of mungbean (Vigna radiata L.). J. Animal Plant Sci. 21(3): 491-497.

Rajendran, G., Singh, F., Desai, A. J. and Archana, G. 2008. Enhanced growth and nodulation of pigeonpea by coinoculation of Bacillus strains along with Rhizobium sp. Bioresource Tech. 99: 4544-4550.

Reis, V.M., Olivares, F.L. and Dobereiner, J. 1994. Improved methodology for isolation of Acetobacter diazotrophicus and confirmation of its habitat. World $J$. Microbiol. Biotech. 10: 101-104.

Sagervanshi, A., Priyanka, K. and Anju, N. 2014. Media optimization for inorganic 
phosphate solubilizing bacteria isolated from agriculture soil. Int. Life Sci. Pharma Res. 2(3):245-255.

Sheng, X.F. and Huang, W.Y. 2002. Mechanism of potassium release from feldspar affected by the strain NBT of silicate bacterium. Acta Pedologica Sinica. 39: 863-871.

Shete, M.H., Murumkar, D.R., Tirmali A.M. and Landge, K.B. 2019. Formulation of culture media for growth of nitrogen fixing, phosphate solubilizing and potash mobilizing bacteria in a consortium. J. Pl. Dis. Sci. 14(1): 41-46.

Singh, A.K., Dipuraj, Harison, H., Yashab, K., Peter, J.K., Mishra, S.K. and Saxena, L. 2014. Optimization of production parameters and evaluation of shelf life of Rhizobium biofertilizers. Elixir. Biol. Tech. 67: 21787-21795.

Smith, D.L. and Hume, D.J. 1987. Comparison of assay methods for N2 fixation utilizing white bean and soybean. Can. J. Plant Sci. 67: 11-19.

Sugumaran, P. and Janarthanam, B. 2007. Solubilization of potassium obtaining minerals by bacteria and their effect on plant growth. World J. Agric. Sci. 3(3): 350-355.

Tarafder, H.K., Dey, A. and Dasgupta S. 2016. Co-inoculation of phosphate solubilizing bacteria and Rhizobia for improving growth and yield of mungbean (Vigna radiate L.). Asian $J$. Soil Sci. 11(1): 207-212.

\section{How to cite this article:}

Ghadge, J. R. and Murumkar, D. R. 2020. Inoculation Effect of Consortium of Rhizobium, PSB and KMB on the Growth and Yield of Soybean. Int.J.Curr.Microbiol.App.Sci. 9(09): 19791993. doi: https://doi.org/10.20546/ijcmas.2020.909.248 